\title{
Study on Ambient Particulate Matter (PM2.5) with Different Mode of Transportation in Dhaka City, Bangladesh
}

\author{
Md. Maruf Hossain ${ }^{1}$, Ahmad Kamruzzaman Majumder ${ }^{2 *}$, Mahmuda Islam ${ }^{3}$ and Abdullah Al Nayeem ${ }^{4}$ \\ ${ }^{1}$ Program Manager, Work for a Better Bangladesh Trust (WBBT); ${ }^{2}$ Founder and President, Center for \\ Atmospheric Pollution Studies (CAPS), Department of Environmental Science, Stamford University Bangladesh; \\ ${ }^{3}$ Senior Lecturer, Department of Environmental Science, Stamford University Bangladesh; and ${ }^{4}$ Research \\ Assistant, Department of Environmental Science, Stamford University Bangladesh
}

*Correspondence: kamrul_sub@ hotmail.com

\begin{abstract}
Air pollution is considered as a threat to the environment in the developing countries. This study aims to quantify the concentration of $\mathrm{PM}_{2.5}$ with relation to mode of transportation in the different areas of the Dhaka city. For this, the concentration of $\mathrm{PM}_{2.5}$ was measured in ambient air with Ecotech Mini 2.5 Sampler and traffic volume survey was conducted in 12 sites across the city in August 2017. The study found that $\mathrm{PM}_{2.5}$ concentrations in mixed and motorized areas were on average higher than non-motorized and vehicle-free area. The maximum concentration of $\mathrm{PM}_{2.5}$ was found in Mirpur-10 $\left(172.2 \mu \mathrm{g} / \mathrm{m}^{3}\right)$ while minimum concentration was in B.C. das street $\left(40 \mu \mathrm{g} / \mathrm{m}^{3}\right)$. This study concluded that increasing the number of vehicles is one of the major sources of pollution of air in Dhaka city. Hence, well-developed public transportation service instead of the private car may contribute to reducing the air pollution in Dhaka city.
\end{abstract}

Keywords: Transport, Pollutant, $\mathrm{PM}_{2.5}$, Dhaka City, Motorization, Ambient, Mode, and Bangladesh.

\section{INTRODUCTION:}

The capital Dhaka located in a central geographical position of Bangladesh that accommodates about $10 \%$ of the nation's population. The mass influx of domestic migration from rural areas for pursuing economic opportunities or in response to climate and environmental disturbances is leading the city as one of the world's fastest growing megacities with a total population of 18.94 million (Dhaka Population, 2019). While being a potential global leader and modern economic hub of Bangladesh, it is experiencing tremendous overcrowding, extensive slum housing and poor sanitation due to lack of infrastructure, formal job opportunities and social services. With these, pollution comes as a byproduct and air pollution is the worst of them all.

Since development must keep going in the country, an air pollutant is increasing in the atmosphere with these developmental activities due to the rapid rising of motor vehicles emissions, biomass burning, lead-acid batteries processing, and paint pigment production which is transported and floated as fine particles (Rouf et al., 2011; Begum et al., 2006; Ahmed et al., 2016).

The government of Bangladesh along with some nongovernmental organizations has taken initiatives to ban the 2-stroke wheeler in 2002 and afterward it helps to improve the quality of air (Ahammad et al., 2010). It was then a successful step since the air quality improved drastically at that time but the present the situation of air quality is too worse to meet the Bangladesh and WHO standard (Ahmed et al., 2007; Begum et al., 2007; Rahman, 2005). Different types of construction activities, diesel run transportation system, trash burning, brick kilns, and industrialization are the major causes of air pollution here (Nayeem, 
2018). Due to the presence of hundreds of brick kilns in and around the Dhaka district, air pollution in Dhaka metro becomes the worst one during the winter season in each year (Ahmed and Hossain, 2008; Nayeem, 2018). Razib et al., 2019 showed in one of his work, the average hourly Air Quality Index score for $\mathrm{PM}_{2.5}$ in Dhaka for all the year round of 2017 and there the maximum number of hours which is 2714 was considered as "Unhealthy".

Air pollution has a severe impact on human health, wildlife, climate, agriculture, and the natural ecosystem (Haque et al., 2017; Salam et al., 2008; Molina and Molina, 2004; Ahmad T. et al., 2018; Molina et al., 2004). A number of epidemiological studies have identified a strong relationship between Particulate Matter and mortality and morbidity (Perez and Reyes, 2002; Lin and Lee, 2004; Namdeo and Bell, 2005). Air pollution is one of the top risk factors of death and disability worldwide. It has been estimated that, air pollution was fifth-ranked mortality risk factor globally in 2017 and was associated with about 4.9 million deaths and 147 million years of healthy life lost (HEI, 2019). In Bangladesh, ambient and indoor $\mathrm{PM}_{2.5}$ is one of the substantial environmental risk, causing about $21 \%$ of all deaths while Bangladesh are the leading country compare to other south Asian countries in terms of air pollution (World Bank, 2018).

Being city of a middle-income country Dhaka experiences 15,000 early deaths along with a pulmonary, respiratory and neurological illness caused by low air quality (Ahmed et al., 2016). According to World Bank's Country Environmental Analysis (CEA) 2018 report, air pollution directs causes to deaths of 46,000 people in yearly in Bangladesh. Ministry of Health and Family Welfare found that, the concentration of lead in blood $(\mathrm{PbB})$ among the residents of the urban areas have reached alarming levels by exceeding the maximum tolerable limit of 10 $\mu \mathrm{g} / \mathrm{dL}$ recommended by WHO (Hossain and Easa, 2012). Furthermore air pollution basically in the form of dust pollution is not only responsible for health hazards but also causes environmental and financial losses. The economic losses of air pollution could range from a low estimate of $\$ 60$ million to a high estimate of $\$ 270$ million, equivalent to $1.7 \%$ to $7.5 \%$ of the Dhaka's gross product (Hossain and Easa, 2012). If this loss is added with traffic congestion, global warming, soiling of materials and aesthetic degradation, the total cost of air pollution would be significantly larger (Hossain and Easa, 2012; Xie et al., 1998).

The less developed countries are suffering more $\mathrm{PM}_{2.5}$ exposure which is four to five times higher than developed countries (Rahman, 2005). Recently, Dhaka became one of the worst cities in the world in terms of air pollution (Alam et al., 2018). In reference to other south and south-east Asian megacities, Dhaka is also suffering from the high level of $\mathrm{PM}_{2.5}$ concentration in the atmosphere (Rana et al., 2016; CASE, 2015; WHO, 2014b; Salam et al., 2008). From 2013-2018, the $\mathrm{PM}_{2.5}$ concentrations in Dhaka city was six times greater than the NAAQS of Bangladesh as well as 813 times higher than the WHO guideline value (Rana et al., 2016; DoE, 2019). In this circumstance, we studied air quality parameters $\left(\mathrm{PM}_{2.5}\right)$ at different locations in the megacity of Dhaka and its relation with modes of transport. The objectives of the study are to determine the variation of $\mathrm{PM}_{2.5}$ concentration between different categories of roads in Dhaka.

\section{MATERIALS AND METHODS:}

\section{Road Categories of this study -}

Vehicle free road: Vehicle free road is a road of a city or town reserved for pedestrian and bicycle use and in which most or all automobile traffic may be prohibited.

Predominant the road by non-motorized transportation: It provides opportunity to change the choice of transport modes to road users of motor vehicles to non-motor vehicles in the local road of the city.

Mixed use road: It allows running of all type of modes of transportation in the city.

Motorized vehicle dominated road: Only motorized vehicles are allowed to run in this type of road in the city.

Study Area: To conduct this study, 12 locations have been identified for data collection. Table 1 shows those twelve selected sampling locations to reflect the contribution to air pollution from different categories of roads which are Vehicle Free (2), Non-Motorized vehicle dominated roads (2), Mixed roads (3) and Motorized vehicle dominated roads (5) in Dhaka. Map of the study is has been shown in Fig 1. 
Table 1: Locations of the Sampling Sites

\begin{tabular}{|c|c|c|}
\hline SN & Locations & Road Type \\
\hline $\mathrm{S} 1$ & Karwan Bazar & \multirow{5}{*}{$100 \%$ Motorized Intersection } \\
\hline $\mathrm{S} 2$ & Shahbag Square & \\
\hline S3 & Suhrawardy College gate & \\
\hline $\mathrm{S} 4$ & Mirpur - 10 & \\
\hline S5 & Gulshan - 1 & \\
\hline S6 & Dhaka University Campus & \multirow{2}{*}{$\begin{array}{c}\text { Predominantly Non-Motorized } \\
\text { Transportation } \\
\end{array}$} \\
\hline S7 & Natun Rasta Zigatola & \\
\hline S8 & Nilkhet & \multirow[t]{2}{*}{ Mixed } \\
\hline S9 & Shat Mosjid Road & \\
\hline S10 & Bijoy Nagar Paltan & \multirow{3}{*}{ Vehicle Free } \\
\hline S11 & B.C. Dash Street & \\
\hline S12 & Kobiraj Lane, Patuyatuli & \\
\hline
\end{tabular}

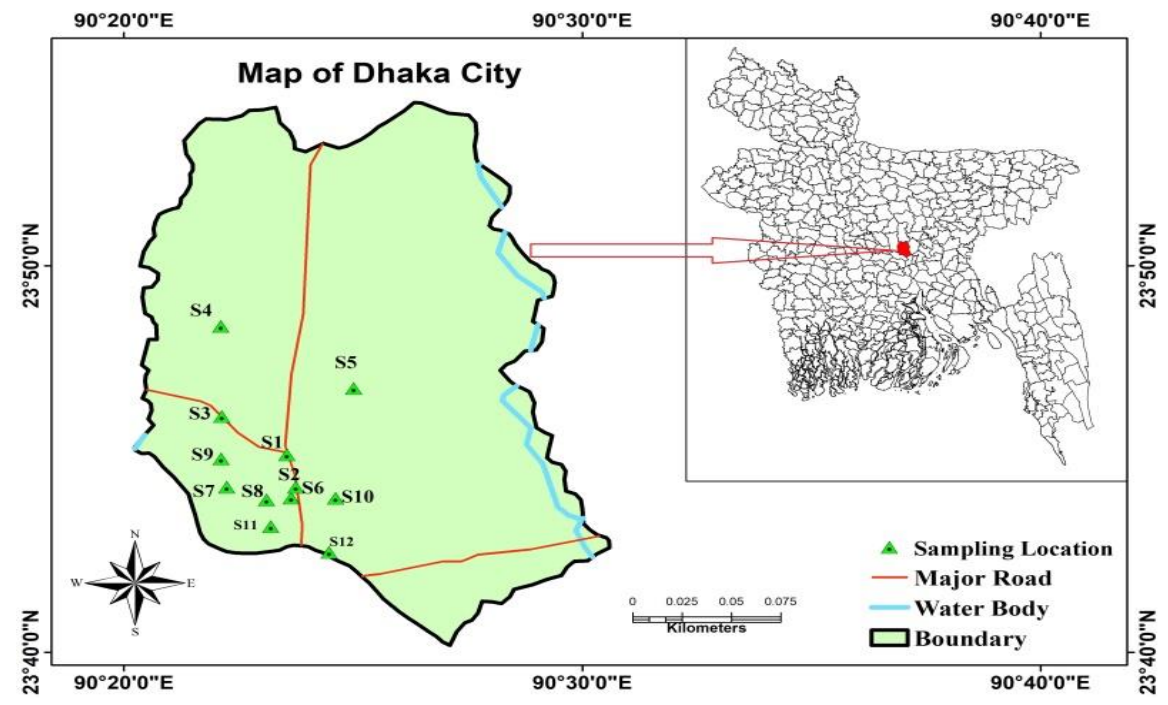

Fig 1: Map of Study Area of the Sampling Sites.

\section{Data Collection and Analysis -}

A traffic survey was conducted by manual counting of vehicles at those 12 locations on selected days during the study period to understand the correlation between PM concentrations and traffic volume. The counting was done at 3 times (morning, afternoon, and evening) in a day for a period of 30 minutes at each location. Air samples of different locations were collected with the help of Ecotech Mini 2.5 sampler for 12 hours in a day (6 $\mathrm{AM}$ to $5 \mathrm{PM}$ ) in the month of August to

\section{RESULT AND DISCUSSION:}

This study found a considerable variation in the mode of transportation indifferent categories of roads at different locations in Dhaka city (Fig 2). The percentage of different vehicles running in the study area is shown in Fig 3. Rickshaw dominates in the predominantly non-motorized and mixed categories of identify the particulate matter with size 2.5 micron $\left(\mathrm{PM}_{2.5}\right)$ concentration following simple gravimetric method. The concentration of $\mathrm{PM}_{2.5}$ is calculated by measuring the weight of filter paper before and after the experiment using the high-resolution electronic balance. $\mathrm{PM}_{2.5}, 12$ hours of concentration converted to 24 hours concentration to identify the AQI position of each study point. Microsoft Excel has been used for different types of data processing, analysis, and presentation.

the road and car dominate the motorized roads. The second position is achieved by car (22\%) in both of the predominantly non-motorized and mixed category of road but in the predominantly motorized road, it is CNG run vehicles. In all of the three categories of roads, motor cycles can be placed in the third position with the percentages of 10,8 and 15 respectively. The 
other types of vehicles found in these roads are a cycle, van/other, bus and pickups. No vehicles were found in vehicle-free roads but huge numbers of pedestrian used all of the roads though pedestrian was not considered during traffic volume survey.

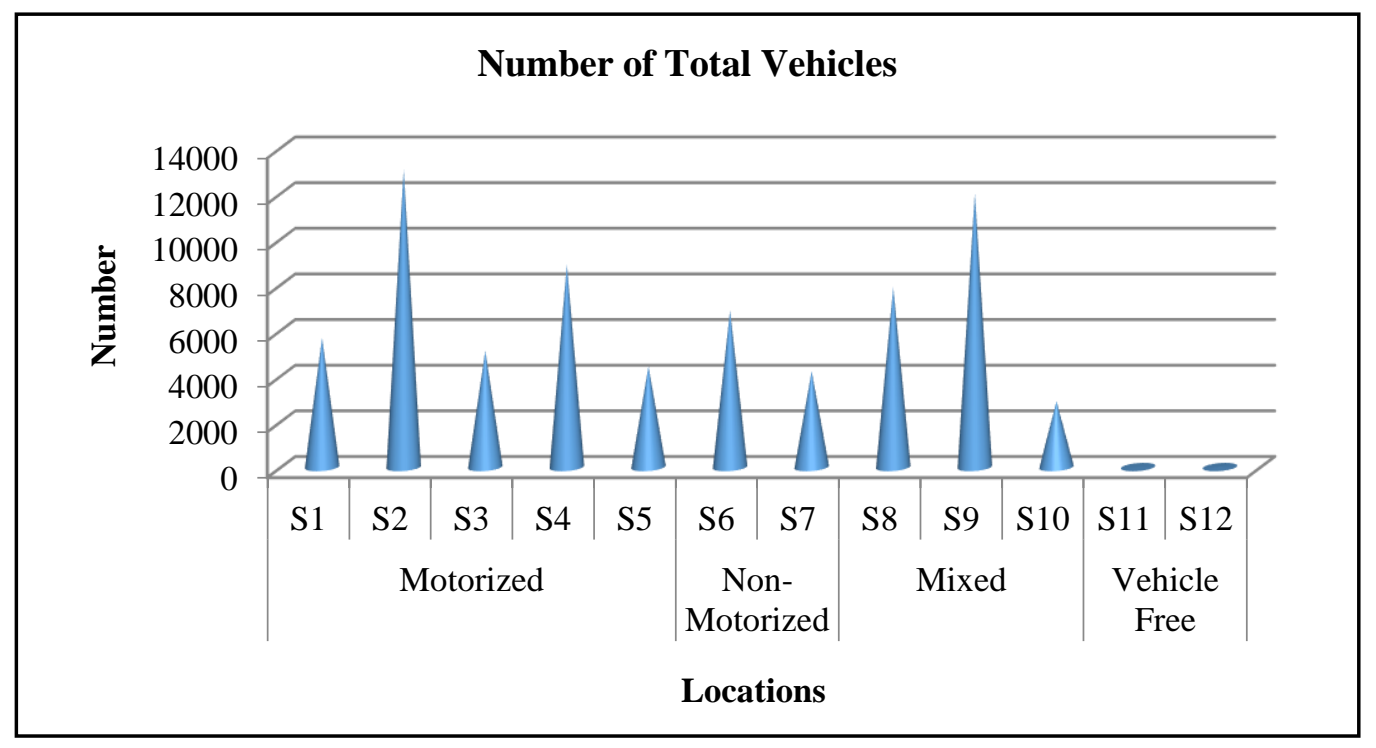

Fig 2: Number of Vehicles in all locations.
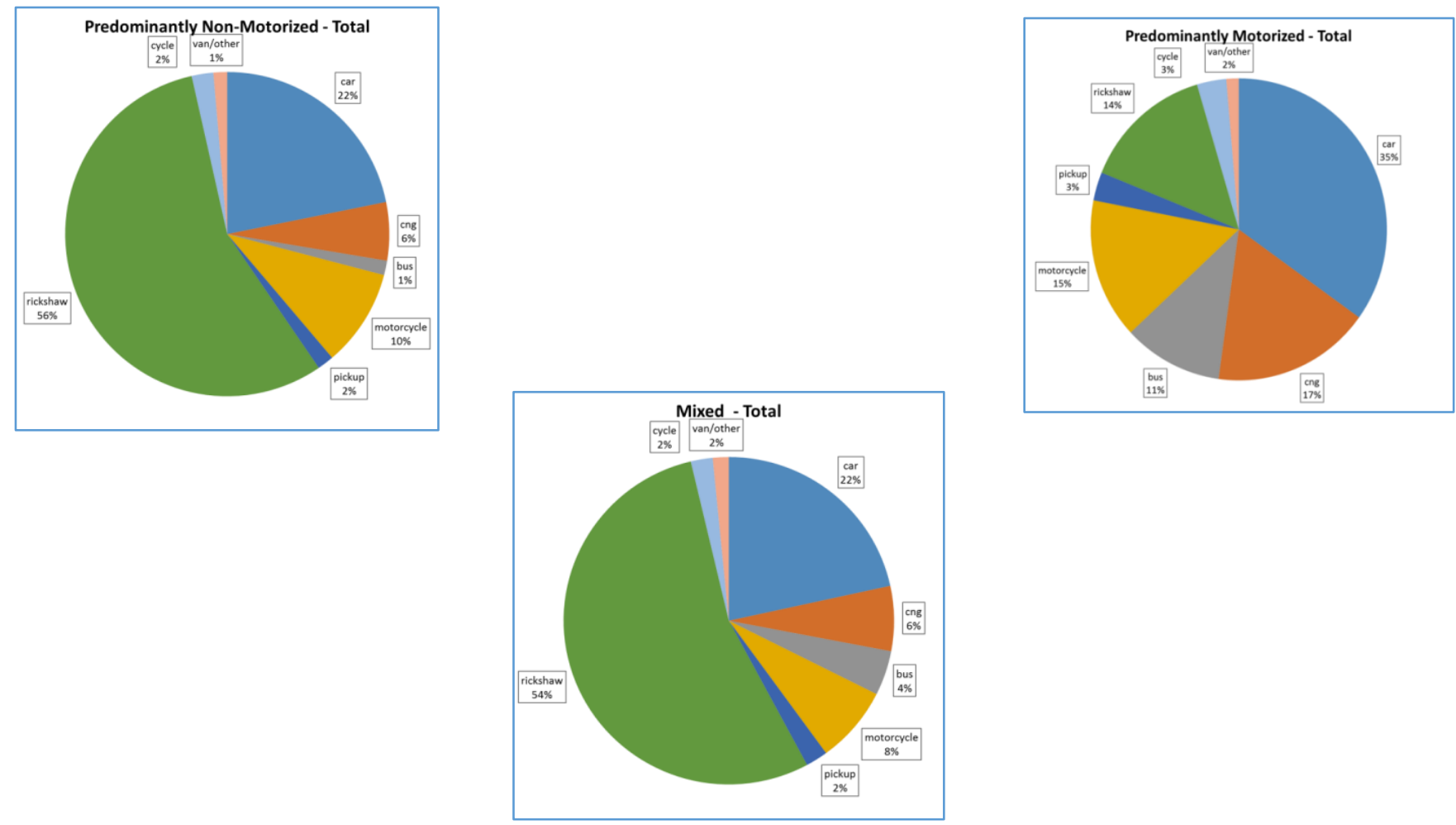

Fig 3: Types of Vehicle running indifferent Category of Roads.

Table 2 showed the concentration of $\mathrm{PM}_{2.5}$ in each sampling site of Dhaka city. Maximum concentration $\left(172.2 \mu \mathrm{g} / \mathrm{m}^{3}\right)$ was found in Mirpur-10 which is one of the largest intersections of four roads in Dhaka city. In addition, the AQI in this intersection was also found "Unhealthy" among the 12 sites. Roads loaded with high PM concentration contain diesel run heavy vehicles instead of the cycle, rickshaw and van (Begum et al., 2011). 
Table 2: Concentration of $\mathrm{PM}_{2.5}$ in different locations

\begin{tabular}{|c|c|c|c|c|c|}
\hline SN & Locations & Road Type & $\begin{array}{c}12 \text { hours } \\
\text { Concentration } \\
\left(\mu \mathrm{g} / \mathrm{m}^{3}\right)\end{array}$ & $\begin{array}{c}\text { Equivalent } \\
\text { Exposure } \\
\text { Level }\left(\mu \mathrm{g} / \mathrm{m}^{3}\right)\end{array}$ & $\begin{array}{c}\text { Air Quality Index } \\
\text { (AQI for } \\
\text { Bangladesh) }\end{array}$ \\
\hline S1 & Karwan Bazar & \multirow{5}{*}{$\begin{array}{c}100 \% \\
\text { Motorized } \\
\text { Intersection }\end{array}$} & 130.20 & 52.1 & Caution \\
\hline S2 & Shahbag Square & & 103.23 & 41.3 & Caution \\
\hline S3 & $\begin{array}{c}\text { Suhrawardy College } \\
\text { gate }\end{array}$ & & 127.35 & 50.9 & Caution \\
\hline S4 & Mirpur - 10 & & 172.23 & 68.9 & Unhealthy \\
\hline S5 & Gulshan - 1 & & 114.63 & 45.9 & Caution \\
\hline S6 & $\begin{array}{c}\text { Dhaka University } \\
\text { Campus }\end{array}$ & \multirow{2}{*}{$\begin{array}{l}\text { Predominantly } \\
\text { Non-Motorized } \\
\text { Transportation }\end{array}$} & 61.79 & 24.7 & Moderate \\
\hline S7 & Natun Rasta Zigatola & & 45.98 & 18.4 & Moderate \\
\hline S8 & Nilkhet & \multirow[t]{3}{*}{ Mixed } & 84.65 & 33.9 & Moderate \\
\hline S9 & Shat Mosjid Road & & 63.50 & 25.4 & Moderate \\
\hline S10 & Bijoy Nagar Paltan & & 123.79 & 49.5 & Caution \\
\hline S11 & B.C. Dash Street & \multirow[t]{2}{*}{ Vehicle Free } & 40.00 & 16.0 & Moderate \\
\hline S12 & $\begin{array}{c}\text { Kobiraj Lane, } \\
\text { Patuyatuli }\end{array}$ & & 45.00 & 18.0 & Moderate \\
\hline
\end{tabular}

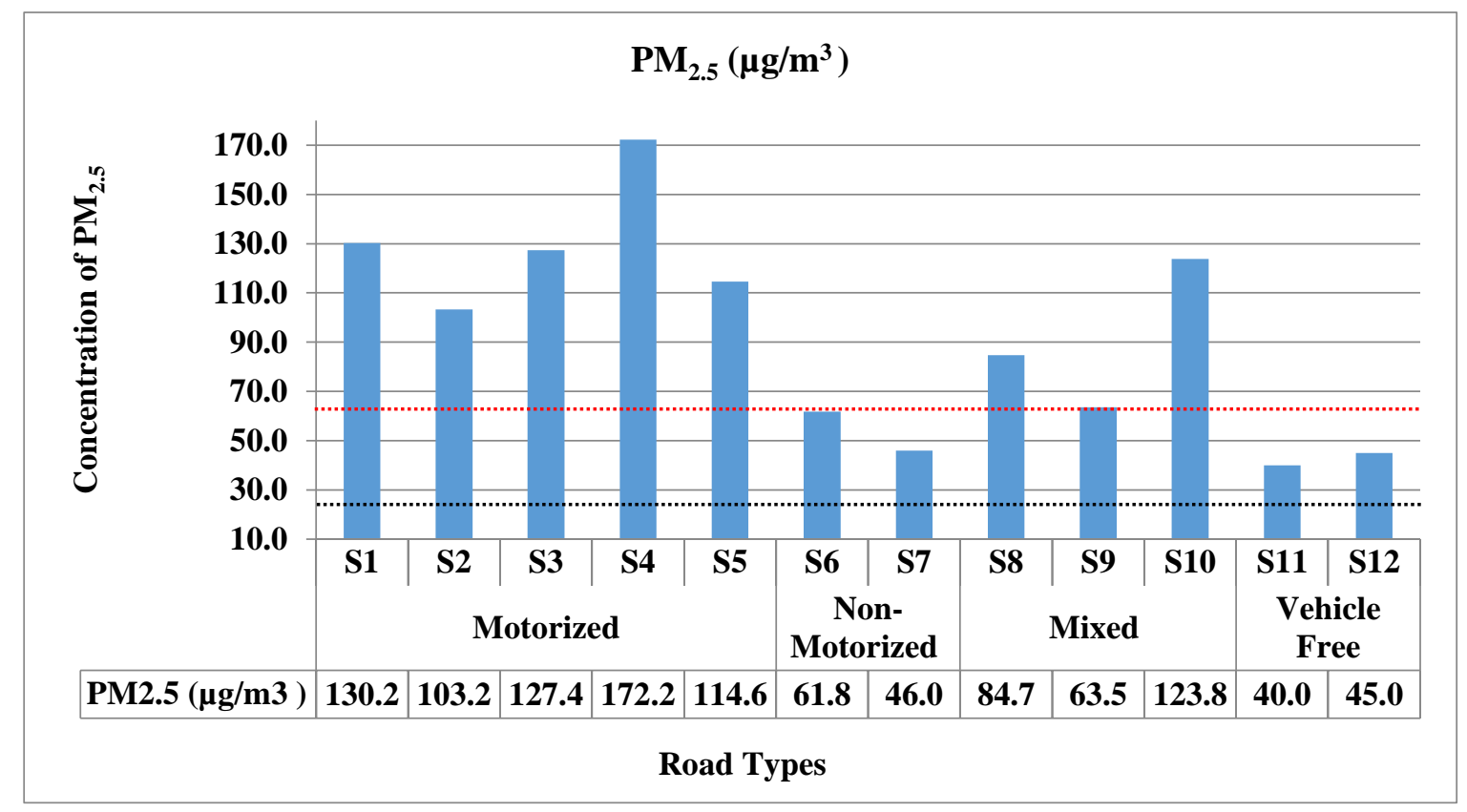

Fig 3: Concentration of $\mathrm{PM}_{2.5}$ in Selected Locations.

Minimum concentration $\left(40 \mu \mathrm{g} / \mathrm{m}^{3}\right)$ was found at B.C. Dash Street which is a vehicle-free road. This road is used only by pedestrians. It is clear from the table that $\mathrm{PM}_{2.5}$ concentration in all the selected locations exceeded WHO standards $\left(25 \mu \mathrm{g} / \mathrm{m}^{3}\right)$ while the concentration in some roads which are basically vehicle free and non-motorized roads are within the Bangladesh standard $\left(65 \mu \mathrm{g} / \mathrm{m}^{3}\right)$ though WHO and Bangladesh standards are set for 24 hours the duration of air sample collection is this study is 12 hours due to 
the unavailability of the instrument. Some of the other studies also found the average concentration of Suspended Particulate Matter (SPM) of $385.3 \mu \mathrm{g} / \mathrm{m}^{3}$ in Dhaka city which is higher than the daily the average given by WHO (Rahman et al., 2013).

Besides, several studies found that PM concentration get much higher during the winter season (DecemberFebruary) in Dhaka city compare to monsoon and premonsoon (Rouf et al., 2011; Razib, 2019). Fig 3 is showing that the contentration of $\mathrm{PM}_{2.5}$ is considerably higher in mixed and motorized roads than vehicle free and predominantly non-motorized roads. It can also be seen that the vehicle free road is comparatively free from the higher PM concentration as the found concentration is within the standard. This road is free from all types of transportation even the rickshaw could not run there. Predominantly non-motorized roads are used mostly by rickshaw along with some cars and motorcycles. For this, probably these roads have a higher concentration of PM than that of vehicle-free road. The $\mathrm{PM}_{2.5}$ concentration in mixed and motorized roads was on average higher than nonmotorized and vehicle free roads. The concentration in the 7 sites of predominantly mixed and motorized areas for $12 \mathrm{hrs}$ already exceeded the maximum recommended limit for $24 \mathrm{hrs}\left(65 \mu \mathrm{g} / \mathrm{m}^{3}\right)$.

This suggests a much higher pollution potential over the typical $24 \mathrm{hrs}$ period in motorized traffic areas. Therefore it can be depicted from the scenario that the concentration of PM in any road is significantly related to number and types of vehicle running on that road which is also analogous to findings of a number of studies (Begum et al., 2013; Guttikunda, 2009; Begun et al., 2004; Begum et al., 2010a; Biswas et al., 2003). Studies have found that, vehicular pollution particularly emission from motorcycles, diesel run heavy trucks and buses are the major contributing sources of air pollution in Dhaka city (Rana et al., 2016) which is a fact for other cities also since automobile exhaust contributing $80 \%$ of the total proportion of fine particles $\left(\mathrm{PM}_{2.5} / \mathrm{PM}_{10}\right.$ ratio) in Bangkok and Thailand (Jinsart et al., 2002).

\section{REFERENCES:}

1. Ahmed, S. and Hossain, I. (2008). Applicability of air pollution modeling in a cluster of brickfields in Bangladesh. Chemical Engi-

\section{CONCLUSION:}

The impacts of increasing motorization of Dhaka transportation is severe and is poised to get worse, with dire consequences for the quality of life and health. The study found that predominantly motorized and mixed category of roads contain the higher concentration of $\mathrm{PM}_{2.5}$ which is almost four times higher than the WHO standard and 2 times higher than Bangladesh national standard and AQI of one 100\% motorized road was found "Unhealthy" while the rest of the sites can be marked as "Caution" and "Moderate". Therefore, it is time to advocate for car control as a way to reduce congestion, pollution and social disruption in Dhaka. Non-motorized forms of transit, including walking, cycling and rickshaw are the life blood of Dhaka, and should be integrated into its future vision as a modern metropolis. There are four rivers around the Dhaka city which might be a great potential way of water transportation. Hence, this type of study is needed in a continuous manner for a long period of time in more locations to provide strong conclusions. Besides, seasonal variation is also an important factor to be studied to see the trend with different modes of transportation.

\section{ACKNOWLEDGEMENT:}

The authors express their gratitude to Debra Efroymson, Joseph Mclntyre and Steven Jones for their suggestions and contribution to carry out this research. The authors are also thankful to Center for Atmospheric Pollution Studies (CAPS), Department of Environmental Science, Stamford University Bangladesh; Department of Urban and Regional Planning, BUET and Work for a Better Bangladesh Trust for their contribution at different stages in this study.

\section{CONFLICTS OF INTEREST:}

The authors declared no potential conflicts of the interest with respect to the research, authorship of this article.

neering Research Bulletin. 12: 28-34.

https://doi.org/10.3329/cerb.v12i0.1495

2. Ahmed, S., Akter, Q.S., Eva, H., and Bhowmik, M. (2016). Traffic policemen in Dhaka city. 11(2): 39-42. 
3. Ahammad, S.S., Ali, M.S., Kaji, M.A., and Kazi, F.K. (2010). Tracking of possible sources of Dhaka city air pollutants. Proc. of International Conference on Environmental Aspects of Bangladesh (ICEAB10). Japan, 136-137.

4. Ahmad T, Uddin ME, Alam MK, Moniruzzaman M, Saha B, Alam M. G, and Hossain I. (2018). Evaluation of Microbial and Physiochemical Properties of Three Selected Lakes Water in Dhaka City, Bangladesh. Scholars Academic J. of Biosciences. 6(2): 230-238. https://doi.org/10.21276/sajb.2018.6.2.17

5. Ahmed, F., Ishiga, H., and Bibi, M.H. (2007). Environmental assessment of Dhaka City (Bangladesh) based on trace metal contents in road dust. Environ Geol. 51: 975-985.

6. Alam, M.Z., Armin, E., Haque, M., Halsey, J., Kayesh, E., and Qayum, A. (2018). Air Pollutants and Their Possible Health Effects at Different Locations in Dhaka City. International J. of Environmental Sci. and Natural Res. 9(4), 1-11.

7. Begum, B.A., Biswas, S.K., and Hopke, K. (2007). Source Apportionment of Air Particulate Matter by Chemical Mass Balance (CMB) and Comparison with Positive Matrix Factorization (PMF) Model. Aerosol and Air Quality Research. 7: 446-468.

https://doi.org/10.4209/aaqr.2006.10.0021

8. Begum, B.A., Biswas, S.K., Hopke, P.K., and Cohen, D.D. (2006). Multi-element Analysis and Characterization of Atmospheric Particulate Pollution in Dhaka. Aerosol and Air Quality Research. 6(4): 334-359.

9. Begum, B.A., Kim, E., Biswas, S.K., and Hopke, P.K. (2004). Investigation of sources of atmospheric aerosol at urban and semi-urban areas in Bangladesh, Atmospheric Environment. 38(19): 3025-3038.

10. Begum, B.A., Nasiruddin, M., and Biswas, S.K. (2010a). Trend and spatial distribution of air particulate matter pollution in Dhaka city. $J$. of Bangladesh Academy of Sciences. 34: 151157. https://doi.org/10.3329/jbas.v34i1.5490

11. Begum, B.A., Hopke, P.K., and Markwitz, A. (2013). Air pollution by fine particulate matter in Bangladesh. Atmospheric Pollution Research. 4(1): 75-86.
12. Begum, B.A., Biswas, S.K., and Hopke, P.K. (2011). Key issues in controlling air pollutants in Dhaka, Bangladesh. Atmospheric Environment. 45(40): 7705-7713.

https://doi.org/10.1016/j.atmosenv.2010.10.022

13. Biswas, S.K., Tarafdar, S.A., Islam, A., Khaliquzzaman, M., Tervahattu, H., and Kupiainen, K. (2003). Impact of Unleaded Gasoline Introduction on the Concentration of Lead in the Air of Dhaka, Bangladesh. J. of the Air and Waste Management Association. 53(11): 13551362.

14. Clean Air and Sustainable Environment (CASE), (2015). Monthly air quality monitoring report. Department of Environment, Dhaka, www.case-moef.gov.bd

15. Dhaka Population. (2019-03-31). Retrieved 2019-04-18, from -

http://worldpopulationreview.com/world-cities/ dhaka/

16. Department of Environment (DoE), (2019). Ambient Air Quality in Bangladesh, Clean Air, and Sustainable Environment the Project, Department of Environment, Ministry of Environment, Forest and Climate Change of the Government of Bangladesh.

17. Guttikunda, S. (2009). Impact Analysis of Brick Kilns on the Air Quality in Dhaka, Bangladesh. Retrieve from:

http://www.indiaenvironmentportal.org.in/filesDh aka-AQ-Brick\%20Kilns.pdf

18. Health Effects Institute. (2019) State of Global Air 2019. Special Report. Boston, MA: Health Effects Institute.

19. Haque, H.A., Huda, N., Tanu, F.Z., Sultana, N., Hossain, M.S.A., and Rahman, M.H. (2017). Ambient Air Quality Scenario In And Around Dhaka City of Bangladesh. 4(x): 203-218

20. Hossain, K.M.A, and Easa, S.M. (2012). Pollutant Dispersion Characteristics in Dhaka City, Bangladesh. Asia-Pacific J. of Atmospheric Science. 48(1): 35-41.

https://link.springer.com/article/10.1007/s13143012-0004-8

21. Jinsart, W., Tamura, K., Loetkamonwit, S., Trepanondh, S., Karita, K., and Yano, E. (2002). Roadside Particulate Air Pollution in Bangkok. J. Air \& Waste Manage. Assoc. 52: 1102-1110. 
22. Lin, J. and Lee, L.C. (2004). Characterization of the concentration and distribution of urban

23. Molina, M.J. and Molina, L.T. (2004). Megacities and atmospheric pollution. J. Air Waste Manage Assoc. 54: 644-680.

https://doi.org/10.1080/10473289.2004.10470936

24. Molina, L.T., Molina, M.J., Slott, R., Kolb, C.E., Gbor, P.K., and Meng, F. (2004). Air quality in selected megacities. 2004. Available at: http://www.awma.org

25. Nayeem, A.A. (2018). Spatiotemporal Variation of Brick Kilns and Its relation to ground level $\mathrm{PM}_{2.5}$ through MODIS Image, Unpublished B.Sc. project, Department of Environmental Science, Stamford University Bangladesh.

26. Namdeo, A. and Bell, M.C. (2005). Characteristics and health implications offline and coarse particulates at the roadside, urban background and rural sites in the UK. Environ Int. 31: 565573. https://doi.org/10.1016/j.envint.2004.09.026

27. Perez, P., and Reyes, J. (2002). Prediction of the maximum of 24-h average of $\mathrm{PM}_{10}$ concentrations $30 \mathrm{~h}$ in advance in Santiago, Chile. Atmos Environ. 36: 4555-4561.

28. Rahman, M. (2005). Monitoring and Characterization of $\mathrm{PM}_{10}$ and $\mathrm{PM}_{2.5}$ Air-borne Particulate Matter in Dhaka city. M.Sc. Thesis, Chemical Engineering Department, Bangladesh University of Engineering and Technology.

29. Rahman, M.A., Rahim, A., Siddique, N., and Alam, A.M.S. (2013). Studies on Selected Metals and other Pollutants in the Urban Atmosphere in Dhaka. Dhaka Univ. J. Sci. 61(2): 41-46.

https://doi.org/10.3329/dujs.v61i1.15094 submicron (PM1) aerosol particles. Atmos Environ. 38: 469-475.

https://doi.org/10.3329/dujs.v61i1.15094

30. Razib. (2019). Seasonal Variation of $\mathrm{PM}_{2.5}$ In Relation to Meteorological Characteristics in Dhaka City, Bangladesh. B.Sc. Project.

31. Rana, M.M., Sulaiman, N., Sivertsen, B., Khan, M.F. and Nasreen, S. (2016). Trends in atmospheric particulate matter in Dhaka, Bangladesh, and the vicinity. Environmental Science and Pollution Research. 23(17): 17393-17403. https://pubmed.ncbi.nlm.nih.gov/27230142/

32. Rouf, M.A., Nasiruddin, M., Hossain, A.M.S., and Islam, M.S. (2011).Trend of Particulate Matter $\mathrm{PM}_{2.5}$ and $\mathrm{PM}_{10}$ in Dhaka City. 46(3): 389-398.

33. Salam, A., Hossain, T., Siddique, M.N.A., and Alam, A.M.S. (2008). Characteristics of atmospheric trace gases, particulate matter, and heavy metal pollution in Dhaka, Bangladesh., Air Quality. Atmosphere and Health. 1 (2): 101-109.

https://doi.org/10.1007/s11869-008-0017-8

34. WHO. (2014b). WHO's Ambient Air Pollution database-update 2014. World Health Organization, Geneva.

35. World Bank. (2018). Enhancing Opportunities for Clean and Resilient Growth in Urban Bangladesh: Country Environmental Analysis of 2018. Washington, DC, The World Bank Group.

36. Xie, J., Brandon, C.J. and Shaj, J.J. (1998). Fighting urban transport air pollution for local and global good: The case of two-stroke engine three-wheelers in Dhaka, World Bank paper, World Bank, Washington, USA. 